\title{
Branding places with social problems: a systematic review (2000-2013)
}

\begin{abstract}
A systematic review was performed to identify case studies published in peer-reviewed journals from January 2000 until May 2013 focusing on current and proposed place branding strategies for places with a negative brand image based on a prominent social problem. The main aim of this paper was to review the case studies in order to identify any underlying themes and the different approaches that have been taken or are recommended by place branding researchers. Twenty-five places with prominent social problems that had been studied with a focus on place branding strategies were identified. The analysis of the case studies focused on three main aspects: place branding strategies, types of social problems, and the role of policy development in addressing the problems. Relevant examples were discussed in each of the three categories. This review shows that place branding strategies can be successful for places with negative images, in particular social problems, however, it is an all-encompassing process that cannot focus on only one aspect (i.e. promotion or tourism).
\end{abstract}

\section{Keywords}

Place branding, social problems, systematic review, policy, place strategy

\section{Introduction}

The literature on place branding can be divided into three groups. Firstly, there are studies about defining place branding and what is included under this umbrella (such as destination branding, nation branding, city branding, public diplomacy), how it can best be used, and the importance of it for nations and cities alike (see for example the work of Anholt, 2005; Dinnie, 2004; Hankinson, 2007; Kavaratzis, 2004). The second group of studies discusses the need for a theoretical base in the field of place branding (Niedomysl and Jonasson, 2012). It includes the role of corporate and identity branding strategies in relation to place branding, models of communication, and models such as Anholt and Hildreth's (2004) brand hexagon. The third group within the place branding literature is comprised of numerous case studies that are either evaluative and analyse the place branding campaigns of specific places, or are descriptive and recommend place branding strategies for a specific place and how they could benefit the place. However, there are not many examples of successful place branding campaigns as even developed countries find brand management a difficult task (Domeisen, 2003).

The need for a systematic review of studies that discuss place branding initiatives is highlighted by the fact that place branding studies often do not evaluate changes in brand image following place branding campaigns (for example Osei and Gbadamosi, 2010; Parkerson, 2007) and when they do, researchers shy away from making generalisations based on the knowledge gained (Niedomysl and Jonasson, 2012). There has not been any comparison or review of different place branding case studies identified in academic literature. However, instead of looking at cases on an individual basis and the place specific problem that they are facing, to advance the field it is important that "researchers ... attempt to advance generalizations based on their empirical work" (Niedomysl and Jonasson, 2012, p.224). Therefore this systematic review focuses on a common problem that often tends to give places a negative image and review the case studies that are available in the literature that fall under this category. The common problem that will be assessed is places with prominent social problems. The main aim of this paper is to review the case studies in order to identify any underlying themes and the different approaches that have been used or are recommended by place branding researchers. This article starts by introducing the theoretical background and methods used to identify and analyse the data followed by a comprehensive analysis and discussion of findings. The article concludes by introducing the limitations and future research areas for this line of investigation into place branding for places with prominent social problems. 


\section{Place branding and social problems}

Anholt describes branding as a combination of "corporate strategy, consumer and stakeholder motivation and behaviour, internal communications ethics and purpose" (Anholt 2005, p. 117). Branding therefore is a holistic approach to influencing consumer perceptions (Anholt, 2010), based on combining physical evidence with intangible aspects of a product or offering to create a unique experience for every consumer. Place branding is an area of branding which looks at how the different physical attributes of a place combine with the intangible elements such as the people and culture to influence the perception of the place. Strategically using place branding to improve the perception of the place is a way of utilising soft power, whereby the place gets what it wants through attraction rather than coercion (Nye, 2004).

The concept of place branding is particularly important for places with social problems because statecraft plays an important role into both the creation and the removal of social problems. Structured branding is necessary to ensure that people's perceptions of a place's brand is an accurate reflection of the place's offerings because positive perceptions encourage desired behaviours (i.e travel to a destination or investment in a company) (Dijksterhuis \& Bargh, 2001). However, the term social problem has its own array of definitions. In this review a social constructivist view of social problems was used, where "social problems are not the result of an intrinsic malfunctioning of society, but are the result of a process of definition in which a given condition is picked out and identified as a social problem" (Blumer, 1971, p.301). Therefore all social problems discussed in this review had to be identified as social problems in the original studies under review. This approach combines both the subjective and the objective definitions often used when discussing social problems (Thio \& Taylor, 2012). The purpose of this research is not to identify the reasons the places under study have developed their social problems, nor is it to discuss in depth the problems that the places have and to what extent. The purpose of this systematic review is to identify the similarities and differences across place branding studies that have already been conducted on places with social problems. The reason that this area of research is important is because of the complex nature of social problems. What might be identified as a problem in one culture is not necessarily thought of as a problem in another. This labelling process of a problem can often impact a place from the perspective of tourism and immigration where different cultures are combined. Likewise, most social problems are not easily solved or simply removed from the place. While place branding can be used to start developments towards improving or removing social problems, this complicated and usually expensive task can take many years.

\section{Methods}

Through the use of systematic literature review procedures, relevant studies were identified and then reviewed to compare the similarities and determine if any generalisations can be made from case studies that discuss place branding for places with prominent social problems.

Fourteen databases (ABI/INFORM Dateline, ABI/INFORM Global, Business Source Complete, EBSCO e-Journals, Emerald Full text, Expanded Academics ASAP, Hospitality and Tourism Complete, Informit Business Collection, Proquest Central, PsycINFO, Science Direct: Business, Management and Accounting, Sociological Abstracts, Sustainable Tourism Online, Web of Science) were selected based on their relevance to the fields of business, branding, tourism and social issues in order to maximise the chances of finding any relevant articles. The databases were searched using a pre-determined set of relevant terms (destination OR place OR location AND social issue OR social problem OR stigma or social behaviour OR negative impact OR excessive OR abuse AND branding OR marketing OR image OR identity OR tourism), limiting results to records published between January 2000 and May 2013. Place branding is a fast-developing area of research and therefore date restriction was added to ensure that the branding practices and the social problems discussed were relevant and add to the discussion on the future of place branding.

After conducting the search, results were collated into endnote, duplicates were removed and the remaining papers $(n=319)$ assessed to determine their relevance. The exclusion criteria were: i) papers not in English ( $n=3)$; ii) studies with no focus on social problems $(n=82)$, 
including articles discussing place branding but not focusing on any form of social problems; iii) studies assessing place branding but with no specific case study ( $n=19)$; iv) studies investigating social problems but not in relation to place branding $(n=199)$, including articles discussing social problems but not in the context of place branding. Following the application of the exclusion criteria 16 original papers were identified.

Backward searching, by reading through the reference lists of the articles already found and looking at potentially relevant articles, and forward searching, using study and author names, were conducted to find other suitable material that cite the studies found during the initial search. After backwards and forwards searching of the original 16 papers, 10 more papers were added. One article discussed three countries separately and therefore was divided into four studies (three countries and a region). As a result of the additional papers and dividing of one paper, there were multiple studies on the same place. This meant that studies were grouped as place studies rather than reviewing each as individual studies. Figure 1 illustrates the search and reviewing process used to identify the 25 cases under review.

\section{Figure 1}

Flowchart of the systematic search process

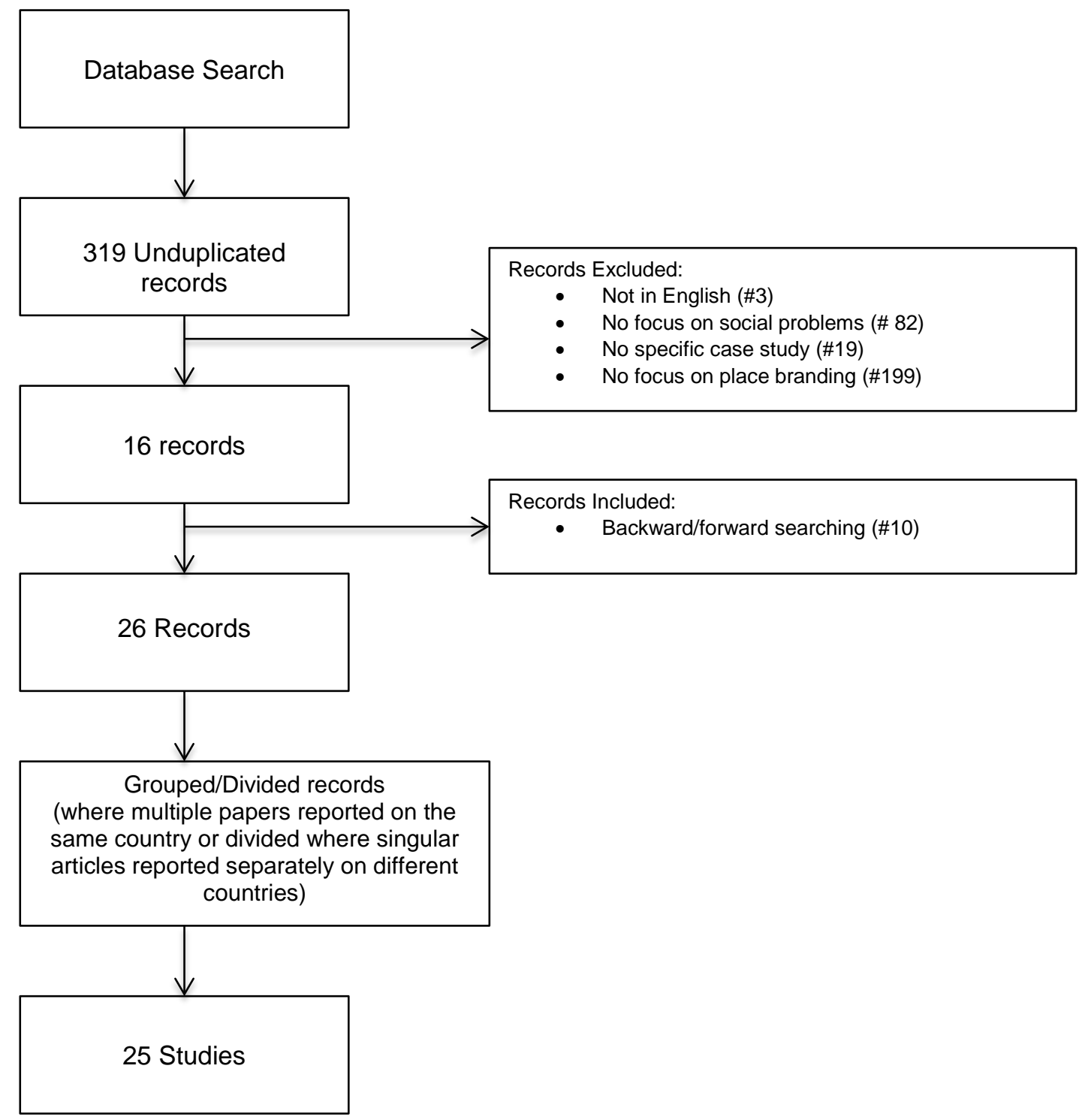


The cases were first assessed to determine if they addressed the eleven factors that influence the presence of social problems. These factors were established through finding commonalities between the literature under review and comparing them to other branding models including the city brand hexagon (Anholt and Hildreth, 2004), the framework of city design management (Harmaakorpi et al, 2008) and dimensions for creative cities (Trueman et al, 2007). These factors were: 1) political stability; 2) government policy; 3) community engagement; 4) social climate; 5) built environment; 6) natural environment; 7) culture and history; 8) economic stability; 9) human capital; 10) security; 11) entertainment. Table 1 presents each study in conjunction with which of the eleven factors it addresses. Based on the works of Nisbet (1971), deficiencies in at least three of these areas, with one being social climate, create an environment for the development of deviance, resulting in one or more prominent social problem. Each case meets this criterion and has a current social problem that is influencing the place's brand.

Table 1

Assessment of 26 records against factors impacting the presence of social problems

\begin{tabular}{|c|c|c|c|c|c|c|c|c|c|c|c|c|c|c|}
\hline Title & Author/s & Year & Location & 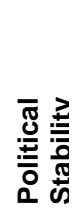 & 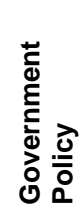 & 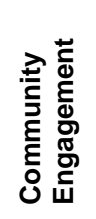 & 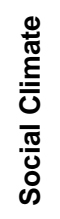 & & 宽 & 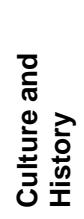 & 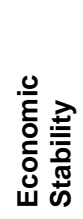 & $\begin{array}{l}\bar{\pi} \\
\frac{\pi}{2} \\
\frac{\pi}{\pi} \\
\frac{5}{\pi} \\
\frac{\pi}{5} \\
\text { Tे }\end{array}$ & 吝 & 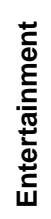 \\
\hline 1. Re-branding Africa & $\begin{array}{l}\text { Osei and } \\
\text { Gbadamosi }\end{array}$ & 2010 & Africa & $\square$ & $\square$ & $x$ & $\square$ & $\square$ & $x$ & $x$ & $\square$ & $\square$ & $\square$ & $\square$ \\
\hline $\begin{array}{l}\text { 2. Changing the Tide; } \\
\text { The campaign to re- } \\
\text { brand Amsterdam }\end{array}$ & $\begin{array}{l}\text { Kavaratzis } \\
\& \\
\text { Ashworth }\end{array}$ & 2006 & Amsterdam & $\mathbf{x}$ & $\square$ & $\square$ & $\nabla$ & $\nabla$ & $\mathbf{x}$ & $\nabla$ & $\mathbf{x}$ & $\square$ & $\mathbf{x}$ & $\nabla$ \\
\hline $\begin{array}{l}\text { 3. A place brand } \\
\text { strategy for the } \\
\text { Republic of Armenia: } \\
\text { 'Quality of context' } \\
\text { and 'sustainability' as } \\
\text { competitive advantage }\end{array}$ & Pant & 2005 & Armenia & $\square$ & $\nabla$ & $x$ & $\nabla$ & $\nabla$ & $\nabla$ & $\nabla$ & $\nabla$ & $\square$ & $x$ & $\nabla$ \\
\hline $\begin{array}{l}\text { 4. "Danger lurks } \\
\text { around every corner": } \\
\text { Fear of Crime and its } \\
\text { Impact on } \\
\text { Opportunities for } \\
\text { Social Interaction in } \\
\text { Stigmatised Australian } \\
\text { Suburbs }\end{array}$ & $\begin{array}{l}\text { Palmer, } \\
\text { Ziersch, } \\
\text { Arthurson } \\
\text { \& Baum }\end{array}$ & 2006 & $\begin{array}{l}\text { Australian } \\
\text { Suburbs }\end{array}$ & $\boldsymbol{x}$ & $\nabla$ & $\nabla$ & $\nabla$ & $\nabla$ & $\square$ & $\mathbf{x}$ & $\nabla$ & 冈 & $\nabla$ & $x$ \\
\hline $\begin{array}{l}\text { 5. It Was Tourism } \\
\text { Repellent, That's What } \\
\text { We Were Spraying": } \\
\text { Natural Amenities, } \\
\text { Environmental Stigma, } \\
\text { and Redevelopment in } \\
\text { a Post-industrial Mill } \\
\text { Town }\end{array}$ & Colocousis & 2012 & $\begin{array}{l}\text { Berlin (New } \\
\text { Hampshire, } \\
\text { USA) }\end{array}$ & $x$ & $\nabla$ & $\nabla$ & $\nabla$ & $\nabla$ & $\nabla$ & $\nabla$ & $\nabla$ & $\square$ & $\nabla$ & $\boldsymbol{x}$ \\
\hline $\begin{array}{l}\text { 6. From schlock to hot: } \\
\text { Shifting perceptions of } \\
\text { Brooklyn }\end{array}$ & Parkerson & 2007 & Brooklyn & $x$ & $\nabla$ & $\nabla$ & $\nabla$ & $\nabla$ & $\mathbf{x}$ & $\nabla$ & $\boldsymbol{x}$ & $\square$ & $\mathbf{x}$ & $\square$ \\
\hline $\begin{array}{l}\text { 7. Securitising the } \\
\text { Caucasus: From } \\
\text { political violence to } \\
\text { place branding in } \\
\text { Chechnya }\end{array}$ & $\begin{array}{l}\text { Wills \& } \\
\text { Moore }\end{array}$ & 2008 & Chechnya & $\nabla$ & $\square$ & $x$ & $\square$ & $\nabla$ & $\square$ & $\square$ & $\nabla$ & $\square$ & $\nabla$ & $x$ \\
\hline $\begin{array}{l}\text { 8. Branding Hrvatska - } \\
\text { a mixed blessing that } \\
\text { might succeed: The } \\
\text { advantage of being } \\
\text { unrecognisable }\end{array}$ & Martinovic & 2002 & Croatia & $\nabla$ & $\square$ & $x$ & $\square$ & $x$ & $\square$ & $\square$ & $\nabla$ & $\square$ & $x$ & $\nabla$ \\
\hline $\begin{array}{l}\text { 9. New communicative } \\
\text { challenges }\end{array}$ & $\begin{array}{l}\text { Peel and } \\
\text { Lloyd }\end{array}$ & 2008 & $\begin{array}{l}\text { Dundee, } \\
\text { Scotland }\end{array}$ & $x$ & $\nabla$ & $\square$ & $\nabla$ & $\square$ & $\nabla$ & $\nabla$ & $\nabla$ & $\square$ & $x$ & $\nabla$ \\
\hline $\begin{array}{l}\text { 10. Brand } \\
\text { development, tourism } \\
\text { and national identity: }\end{array}$ & Hall & 2002 & $\begin{array}{l}\text { Ex- } \\
\text { Yugoslavia }\end{array}$ & $\square$ & $\nabla$ & $x$ & $\nabla$ & $x$ & $\square$ & $\nabla$ & $\square$ & $\nabla$ & $\nabla$ & $\boldsymbol{x}$ \\
\hline
\end{tabular}




\begin{tabular}{|c|c|c|c|c|c|c|c|c|c|c|c|c|c|c|}
\hline $\begin{array}{l}\text { the re-imaging of } \\
\text { former Yugoslavia } \\
\text { (Section on Serbia is } \\
\text { place of study number } \\
21 \text { ) }\end{array}$ & & & & & & & & & & & & & & \\
\hline $\begin{array}{l}\text { 11. The children's city } \\
\text {-- The transition from } \\
\text { a negative to a positive } \\
\text { city image }\end{array}$ & $\begin{array}{l}\text { Herstein \& } \\
\text { Jaffe }\end{array}$ & 2007 & $\begin{array}{l}\text { Holon } \\
\text { (Israel) }\end{array}$ & $x$ & $\nabla$ & 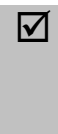 & $\nabla$ & $\square$ & $\square$ & $\nabla$ & $\sqrt{ }$ & $x$ & $x$ & $\nabla$ \\
\hline $\begin{array}{l}\text { 12.When satire is } \\
\text { serious: how political } \\
\text { cartoons impact a } \\
\text { country's brand }\end{array}$ & $\begin{array}{l}\text { Bigi, } \\
\text { Plangger, } \\
\text { Bonera \& } \\
\text { Campbell }\end{array}$ & 2011 & Italy & $\square$ & $x$ & $x$ & $\square$ & $x$ & $x$ & $\nabla$ & $x$ & $x$ & $\mathbf{x}$ & $\mathbf{x}$ \\
\hline $\begin{array}{l}\text { 13. Creative } \\
\text { dimensions for } \\
\text { branding and } \\
\text { regeneration: } \\
\text { Overcoming negative } \\
\text { perceptions of a city }\end{array}$ & $\begin{array}{l}\text { Trueman, } \\
\text { Cook \& } \\
\text { Cornelius }\end{array}$ & 2007 & $\begin{array}{l}\text { Manningham } \\
\text { District in } \\
\text { Bradford } \\
\text { (UK) }\end{array}$ & $x$ & $\sqrt{V}$ & $\nabla$ & $\square$ & $\nabla$ & $\nabla$ & $\sqrt{v}$ & $\nabla$ & $\nabla$ & $\nabla$ & $\nabla$ \\
\hline $\begin{array}{l}\text { 14. Slum tourism, city } \\
\text { branding and social } \\
\text { urbanism: the case of } \\
\text { Medellin, Colombia }\end{array}$ & $\begin{array}{l}\text { Hernandez } \\
\text {-Garcia }\end{array}$ & 2013 & $\begin{array}{l}\text { Medellin, } \\
\text { Columbia }\end{array}$ & $x$ & $\sqrt{V}$ & $\nabla$ & $\nabla$ & $\nabla$ & $\nabla$ & $\sqrt{ }$ & $\nabla$ & $\nabla$ & $\nabla$ & $x$ \\
\hline $\begin{array}{l}\text { 15. Branding Post- } \\
\text { Conflict Destinations }\end{array}$ & $\begin{array}{l}\text { Vitic \& } \\
\text { Ringer }\end{array}$ & 2007 & Montenegro & $\square$ & $\nabla$ & $\nabla$ & $\square$ & $\square$ & $\checkmark$ & $\nabla$ & $\nabla$ & $x$ & $\nabla$ & $\square$ \\
\hline $\begin{array}{l}16 . \text { Rebranding } \\
\text { Nigeria: the role of } \\
\text { advertising and public } \\
\text { relations at correcting } \\
\text { Nigeria image }\end{array}$ & $\begin{array}{l}\text { Adebola, } \\
\text { Igbekele, } \\
\text { Olajide \& } \\
\text { Lamidi }\end{array}$ & 2012 & Nigeria & $\square$ & $\nabla$ & $\square$ & $\nabla$ & $\nabla$ & $x$ & $\nabla$ & $\square$ & $x$ & $\square$ & $x$ \\
\hline $\begin{array}{l}\text { 17. Effects of the } \\
\text { Electronic Nigerian } \\
\text { Money Fraud on the } \\
\text { Brand Equity of } \\
\text { Nigeria and Africa }\end{array}$ & $\begin{array}{l}\text { Viosca, } \\
\text { Bergiel \& } \\
\text { Balsmeier }\end{array}$ & 2004 & Nigeria & $\square$ & $\nabla$ & $\nabla$ & $\square$ & $x$ & $x$ & $x$ & $\checkmark$ & $\nabla$ & $\nabla$ & $x$ \\
\hline $\begin{array}{l}\text { 18. The challenge of } \\
\text { re-branding } \\
\text { progressive countries } \\
\text { in the Gulf and Middle } \\
\text { East: Opportunities } \\
\text { through new } \\
\text { networked } \\
\text { engagements versus } \\
\text { constraints of } \\
\text { embedded negative } \\
\text { images }\end{array}$ & $\begin{array}{l}\text { Cooper \& } \\
\text { Momani }\end{array}$ & 2009 & $\begin{array}{l}\text { Oman, } \\
\text { United Arab } \\
\text { Emirates and } \\
\text { Qatar }\end{array}$ & $\nabla$ & $\sqrt{ }$ & $\nabla$ & $\square$ & $x$ & $x$ & $\nabla$ & $\nabla$ & $\nabla$ & $\nabla$ & $x$ \\
\hline $\begin{array}{l}\text { 19. Branding slums: a } \\
\text { community-driven } \\
\text { strategy for urban } \\
\text { inclusion in Rio de } \\
\text { Janeiro }\end{array}$ & Torres & 2012 & $\begin{array}{l}\text { Rio De } \\
\text { Janeiro }\end{array}$ & $x$ & $\nabla$ & $\nabla$ & $\square$ & 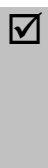 & $\nabla$ & $\sqrt{ }$ & $\nabla$ & $\nabla$ & $x$ & $\nabla$ \\
\hline $\begin{array}{l}\text { 20. National identity } \\
\text { lite: Nation branding } \\
\text { in post-Communist } \\
\text { Romania and Bulgaria }\end{array}$ & $\begin{array}{l}\text { Kaneva } \\
\text { and } \\
\text { Popescu }\end{array}$ & 2011 & $\begin{array}{l}\text { Romania and } \\
\text { Bulgaria }\end{array}$ & $\square$ & $\sqrt{\square}$ & $x$ & $\square$ & $x$ & $\nabla$ & $\nabla$ & $x$ & $\nabla$ & $x$ & $\sqrt{V}$ \\
\hline $\begin{array}{l}\text { 21. Rukai indigenous } \\
\text { tourism: } \\
\text { Representations, } \\
\text { cultural identity and Q } \\
\text { method }\end{array}$ & Hunter & 2011 & $\begin{array}{l}\text { Rukai } \\
\text { (Taiwan) }\end{array}$ & $x$ & $\nabla$ & $\nabla$ & $\square$ & $x$ & $\checkmark$ & $\sqrt{V}$ & $\checkmark$ & $x$ & $x$ & $\nabla$ \\
\hline $\begin{array}{l}\text { 22. Tourism } \\
\text { destination brand } \\
\text { identity: the case of } \\
\text { Slovenia }\end{array}$ & $\begin{array}{l}\text { Konecnik } \\
\text { and Go }\end{array}$ & 2007 & Slovenia & $\nabla$ & $\nabla$ & $\square$ & $\nabla$ & $x$ & $\square$ & $\nabla$ & $\square$ & $\nabla$ & $\square$ & $\mathbf{x}$ \\
\hline $\begin{array}{l}\text { 23. Branding Thailand: } \\
\text { Correcting the } \\
\text { negative image of sex } \\
\text { tourism }\end{array}$ & $\begin{array}{l}\text { Nuttavuthi } \\
\text { sit }\end{array}$ & 2007 & Thailand & $x$ & $\nabla$ & $\nabla$ & $\nabla$ & $\square$ & $\square$ & $\nabla$ & $\nabla$ & $x$ & $\nabla$ & $\square$ \\
\hline $\begin{array}{l}\text { 24. Stigma and } \\
\text { Attachment: } \\
\text { Performance of } \\
\text { Identity in an }\end{array}$ & $\begin{array}{l}\text { Broto, } \\
\text { Burningha } \\
\text { m, Carter } \\
\text { \& Elghali }\end{array}$ & 2010 & $\begin{array}{l}\text { Tuzla, } \\
\text { (Bosnia\& } \\
\text { Herzegovina }\end{array}$ & $x$ & $\sqrt{V}$ & $x$ & $\square$ & $\nabla$ & $\nabla$ & $\sqrt{ }$ & $\nabla$ & $x$ & $\nabla$ & $x$ \\
\hline
\end{tabular}




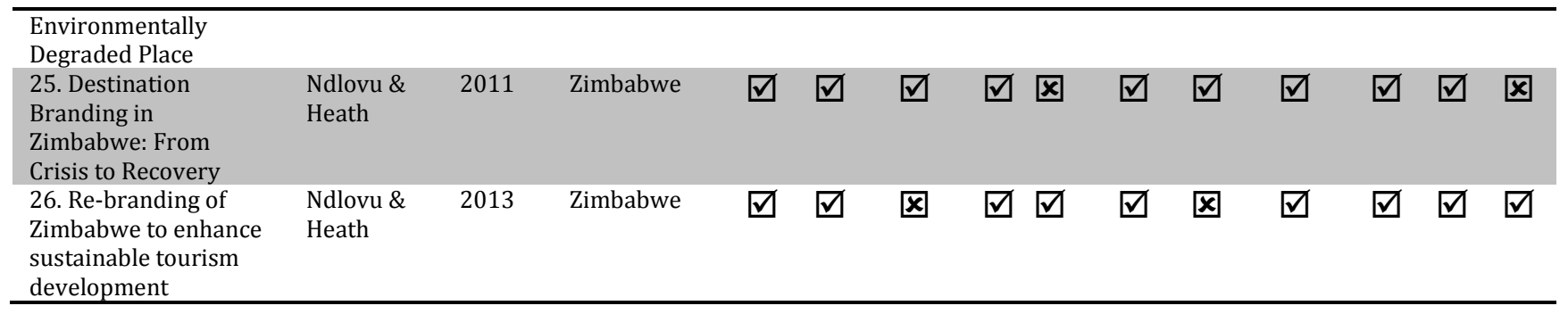

Once the cases were classified as meeting the situational requirements for social problems, they were analysed to determine whether they are descriptive or evaluative studies (Table 2). Descriptive studies have a focus on places with a need for place branding and made recommendations on how to proceed. Evaluative studies address cases where place branding initiatives had been introduced and to what effect. These studies also make further recommendations for the place. From here, a coding system was used to break down the studies so that they could be assessed on their responses to different benchmark components.

Table 2

Social problems of places and classification of studies

\begin{tabular}{|c|c|c|c|}
\hline Place & Social Problems & Evaluative & Descriptive \\
\hline Africa & $\begin{array}{l}\text { Poverty, underdevelopment, } \\
\text { corruption, insecurity, famine, disease }\end{array}$ & & $\bar{x}$ \\
\hline Amsterdam & Illicit drug use, prostitution & $\mathrm{x}$ & \\
\hline Armenia & $\begin{array}{l}\text { Ex-soviet, political instability, conflict } \\
\text { with neighbouring countries }\end{array}$ & & $x$ \\
\hline $\begin{array}{l}\text { Australian Suburbs } \\
\text { in Adelaide }\end{array}$ & High crime rates, violence, drug abuse & $x$ & \\
\hline Berlin (USA) & $\begin{array}{l}\text { Environmental degradation } \\
\text { diminishing life chances, low rent from } \\
\text { absentee land lords has seen an } \\
\text { increase in low income residents }\end{array}$ & & $x$ \\
\hline Brooklyn (USA) & $\begin{array}{l}\text { Questionable place for business, } \\
\text { corruption }\end{array}$ & & $x$ \\
\hline Chechnya & $\begin{array}{l}\text { Political instability, high crime and } \\
\text { violence, insecurity }\end{array}$ & & $x$ \\
\hline Croatia & $\begin{array}{l}\text { Social exclusion, high unemployment, } \\
\text { corruption }\end{array}$ & & $x$ \\
\hline Dundee (Scotland) & $\begin{array}{l}\text { Social exclusion, high unemployment, } \\
\text { poor social housing }\end{array}$ & & $x$ \\
\hline $\begin{array}{l}\text { Ex-Yugoslavian } \\
\text { Nations }\end{array}$ & $\begin{array}{l}\text { Political and economic instability and } \\
\text { resulting problems i.e poverty, } \\
\text { corruption and crime }\end{array}$ & & $\mathrm{x}$ \\
\hline Holon (Israel) & High crime and violence & $x$ & \\
\hline Italy & $\begin{array}{l}\text { Highly publicised Legal and sexual } \\
\text { indiscretions of leader, Social tensions } \\
\text { and student strikes }\end{array}$ & $x$ & \\
\hline Manningham (UK) & $\begin{array}{l}\text { Post-industrial ramifications, ethnic } \\
\text { diversity, poverty }\end{array}$ & $x$ & \\
\hline Medellin (Columbia) & Slums and poverty & & $\mathrm{x}$ \\
\hline Montenegro & $\begin{array}{l}\text { Corruption, organised crime, high } \\
\text { unemployment }\end{array}$ & & $x$ \\
\hline Nigeria & $\begin{array}{l}\text { Corruption, insecurity, instability, } \\
\text { fraud, crime }\end{array}$ & $x$ & $x$ \\
\hline Oman, UAE, Qatar & Corruption, Cronyism, Nepotism & & $x$ \\
\hline Rio de Janeiro & Slums, poverty, unskilled & $x$ & \\
\hline $\begin{array}{l}\text { Romania and } \\
\text { Bulgaria }\end{array}$ & $\begin{array}{l}\text { Former communist associations, } \\
\text { poverty, corruption, economic } \\
\text { instability }\end{array}$ & $x$ & \\
\hline
\end{tabular}




\begin{tabular}{llll}
\hline Rukai (Taiwan) & Cultural tourism & $\mathrm{x}$ & $\mathrm{x}$ \\
Serbia & $\begin{array}{l}\text { Ethnic diversity and instability, } \\
\text { Organised crime, corruption }\end{array}$ & $\mathrm{X}$ & $\mathrm{X}$ \\
Slovenia & $\begin{array}{l}\text { Economic instability, former } \\
\text { Yugoslavian associations }\end{array}$ & $\mathrm{x}$ & \\
$\begin{array}{l}\text { Thailand } \\
\text { Tuzla, Bosnia and } \\
\text { Herzegovina }\end{array}$ & $\begin{array}{l}\text { Sex tourism } \\
\text { Environmental degradation, } \\
\text { unemployment, poverty }\end{array}$ & $\mathrm{x}$ & \\
$\begin{array}{l}\text { Poverty, environmental degradation, } \\
\text { inequality, political conflict, insecurity, } \\
\text { high unemployment }\end{array}$ & $\mathrm{x}$ & 14 \\
\hline
\end{tabular}

\section{Findings and discussion}

Place branding campaigns have been implemented with varying results. The aim of this review was to highlight commonalities between place branding campaigns for places that have prominent social problems. The review consists of twenty-five places that have been evaluated based on their implementation of place branding strategies or on their need for place branding. The evaluation of these studies can provide insight to brand managers on the development and implementation of place branding. The main themes that arose in the literature were place branding strategies, types of social problems, and policy development as the most beneficial strategy.

\section{Place branding strategies}

Of the twenty-five places being studied, nine looked at nations, eight looked at cities, three looked at regions, and five looked at other variations including continents, suburbs/districts and smaller towns (see Table 1). While all the studies discussed elements or branches of place branding, not all self-identified as being place branding studies. Eight of the places under review identified as place branding studies while six were nation branding studies, four were city branding studies and four were destination branding studies. The final three studies did not identify as investigating place branding or one of its branches, but after review were found to focus on major elements of a place branding campaign making them comparable to those that did identify under the place branding umbrella (Broto et al., 2010; Colocousis, 2012; Palmer et al., 2006). Some studies showed that even though place branding was used, it did not translate into a measurable change to brand perception. Brand awareness was often increased with knowledge of the selected theme reaching the desired target markets, however, other developments and brand improvements were not clearly communicated in conjunction with the place theme (Kavaratzis \& Ashworth, 2006; Martinovic, 2002; Kaneva \& Popescu, 2011; Konecnik \& Go, 2007). What this highlights is that too much emphasis is often put on advertising and merchandising and not enough focus on development and promotion based around the positive changes.

There are three examples of creating a successful place brand that were developed around the potential of the place and corresponded with the people and businesses already established (Peel \& Lloyd, 2008; Herstein \& Jaffe, 2007; Parkerson, 2007). What stands out for these place branding campaigns is that they made the decision to act, developed a plan that included establishing set brand managers, looked for an opportunity based on what was available and took steps to enhance that opportunity. Dundee and Brooklyn (Peel \& Lloyd, 2008; Parkerson, 2007) are both cases that have been successful in changing the image of the places. They were able to do this because they took advantage of then present situations (the permanent mooring of exploration ship 'Discovery' and the Manhattan housing boom that forced local artists to relocate, respectively) and through innovative leadership implemented policy change, natural and built environment development and enhancement of entertainment options to take full advantage of the situation. The strategies used such as policy to develop better public housing and communication alignment with local business to present a unified brand across the city have meant Dundee moved away from being a post-industrial town with poor social housing areas. The city now attracts both local and national acceptance and investment in the Discovery theme, and attracts both visitors and new residents. Likewise, 
Brooklyn has become a cultural hub of New York City attracting artists and young adults to the district that combines modernity, culture and history into its environment. It was achieved by using policy to keep housing prices low, develop shared areas such as Brooklyn Bridge Park and other areas and also partnerships with local university to encourage higher enrolment numbers and businesses that attract university students to the residential areas surrounding the university. Holon is the other highly successful attempt to rebrand a place with a prominent social problem (Herstein \& Jaffe, 2007). This campaign used predetermined planning to identify and enhance key areas of development. Through formative research the city evaluated its perceptions of people in the city and people in other cities in Israel. It was able to use this research to evaluate the changes implemented and see whether changes to perception of the city had occurred. Holon successfully changed from a place known for crime and violence to 'The Children's City'.

What these three campaigns have in common is that once the decision was made to brand the cities, a set planning process was implemented. Holon was very structured in that it followed a five-stage plan (diagnosis, vision, image, assimilation and control) whereas Dundee, once realising the potential of the Discovery theme, broke their approach into three categories: aim, structure and leadership, and landscape infrastructure and environment. Brooklyn on the other hand stayed away from creating a corporate identity through the creation of a logo and strapline and used a multi-layered approach to change the perceptions of Brooklyn instead. At first they created a desirable environment based around increasing cultural appeal, then developed policy to ensure it remained affordable to their target market and finally revitalised major areas including Brooklyn Bridge Park, major sports areas and the business and retail sector. The strategies used by these places did not focus on the social problems present. Instead, they made strategic decisions that would help the selected place brand as well as aid in the improvement of the social problems. This shows that it is important attention isn't drawn to 'fixing' the social problem but also that the place branding efforts don't ignore that the problem is there.

\section{Social problems}

The social problems prevalent in the case studies varied greatly (see Table 2). They can however often be associated with the general state of the place, especially for nation studies. Although many places may be affected by multiple interconnected problems, this review focuses only on social problems identified in the analysed articles. For example, developing nations tend to have problems with poverty, crime, instability and security (Hernandez-Garcia, 2013; Hunter, 2011; Osei and Gbadamosi, 2010). Places in transition such as the exYugoslavian states often have concerns with problems that cause social exclusion including corruption, conflict, high unemployment and crime (Broto, 2010; Colocousis, 2012; Hall, 2002; Pant, 2005). Developed places tend to have problems relating to violence, illicit drug use and high unemployment (Herstein and Jaffe, 2007; Kavaratzis and Ashworth, 2006; Palmer et al, 2006).

The identified studies can be divided into two categories, evaluative or descriptive. The studies of Nigeria and Slovenia fall into both categories as one of the studies included for each place are evaluative (Adebola et al, 2012; Konecnik and Go, 2007) while the other is descriptive (Hall, 2002; Viosca, 2004). Of the remaining twenty-three places, eleven are evaluative and twelve are descriptive. Table 2 lists the specific social problems that are discussed as being associated with each place or were associated with each place before place branding initiatives were implemented and whether the study is evaluative or descriptive. The main foci of the studies were branding potential, limits, stigmatisation, brand image, brand identity, brand equity, culture and regeneration, however many of the studies identified several of these themes. Of the twenty-five places, six of them included the objective of discussing the place branding potential for the place (e.g. Cooper and Momani, 2009), six of them discussed the limiting factors of creating a successful place brand for the place (e.g. Adebola et al, 2012; Viosca et al, 2004), six studies approached the research by focusing on how stigmatisation effects place branding initiatives (e.g. Broto et al, 2012), twelve of the studies objective includes looking at the brand image of the place (e.g. Kaneva and Popescu, 2011), seven looked at the importance of creating a brand identity (e.g. Hall, 2002), two specifically mentioned the importance of developing good brand equity in their objectives (e.g. Bigi et al, 2011), two focused specifically on how culture influences place 
branding (e.g. Hunter, 2011), and five had the objective of exploring regeneration or renewal in conjunction with developing a stronger place brand (e.g. Colocousis, 2012).

\section{Policy development}

Policy development was the main strategy that was considered for places with social problems as evident in the literature (Herstein \& Jaffe, 2007; Osei \& Gbadamosi, 2010; Pant, 2005; Palmer et al; 2006). The policy that was implemented or was being recommended to counter a social problem was either to deal directly with the problem or it related to concerns that fuelled the problem. As exampled in Dundee and Adelaide amongst others (Peel \& Lloyd, 2008; Palmer et al, 2006), places with high violence and crime were often linked to poor social housing. This meant policy was either introduced or recommended to improve these areas through infrastructure and the availability of public amenities, along with inclusion of green spaces, programmes to encourage social interaction and policy to both physically and socially integrate the areas into the urban fabric (Palmer et al, 2006; Peel \& Lloyd, 2008; Colocousis, 2012; Parkerson, 2007; Trueman et al, 2007; Hernandez-Garcia, 20013; Torres, 2012). Several cases highlighted government and business corruption or indiscretion as a prominent social problem. Of the places that had implemented strategies to counteract this none were successful because if the government did not entirely support the policy, its implementation was not going to be successful (Wills \& Moore, 2008; Cooper \& Momani, 2009; Bigi et al, 2011). Without cultural change from a top down approach and officials leading through example, improving brand image relating to these problems is a difficult task.

Policy appears to be the key to success and not all policy needs to be heavily funded. In the cases of many of the African examples (Osei \& Gbadamosi, 2010; Adebola et al, 2012; Ndlovu \& Heath, 2011; Ndlovu \& Heath, 2013; Viosca et al, 2004), faced with a myriad of social problems to overcome, including government corruption, money was often a downfall for campaigns. It is important that these places use the available funding more efficiently. Instead of spending the entire budget on promotion as seen in the first Nigerian place branding effort introduced in the literature (Adebola et al., 2012), it would have been more beneficial to use at least some of the funds to introduce policies encouraging investment in the country and supporting the necessary infrastructure. It is therefore important for places with social problems to realise that simply introducing positive communication and ignoring the problems in a hope that other stakeholders will as well is unlikely to be successful. Although it is not possible to remove the problems entirely, it is possible to show progress and encourage interest in what the place has to offer. This interest can be shown in the form of monetary investment as well as partnerships to strengthen development efforts.

Few studies made reference to combining two seemingly unrelated themes - social problems and positive place branding. The two studies that addressed this combination looked at the possibility of using informal settlements as part of a place branding campaign (Torres, 2012; Hernandez-Garcia, 2013). These campaigns approached the challenge of slum branding differently, looking at combining the history of slums and the present reality to give a different meaning to the perceived social problem. The efforts to urbanise, rebrand and include these settlements into the cities were partially successful, however, the studies highlighted the reluctance of the governments to use the successes and incorporate them into part of the whole city branding efforts. This reluctance highlights the limits to the place branding efforts of the settlements in that without further government assistance efforts are stifled. Once again, this is where policy is important to the development of place management and branding. The difference in the two cases is highlighted by the increased involvement of the government in Medellin (developing transport infrastructure inclusion programmes) (Hernandez-Garcia, 2013) and in Rio where the success of the program was limited by visitor's ability to visit the slum or access the products they were developing (Torres, 2012). Although both touched on the concept of an ambi-brand ("relatively ambiguous brands that are flexible and draw on culture, advertising, and play different roles to traditional brands") (Brown, 2006 p. 64) by suggesting the inclusion of a generally perceived negative aspect of a place (a slum) into the place branding initiative of the larger area, they did not come to any conclusions about the possibility of place branding in the context of brands having multiple perceptions for the same group of people. Slum tourism is one area that is starting to touch on this concept and although not applicable to every place, in terms of places with social problems that can be perceived differently by different people it is an area for further development. 


\section{Conclusions}

Although this is just a start towards developing place branding theory specifically for places with social problems, there are many directions that can be addressed in conclusion of this systematic review. The present systematic review identified twenty-five cases of places with prominent social problems that had been studied with a focus on place branding strategies. The analysis of the case studies focused on three main aspects: place branding strategies, types of social problems, and the role of policy development in addressing the problems. It is often hard to say which of these campaigns if maintained or implemented will be successful, but it is clear that ignoring the problem or merely promoting the chosen logo and strapline is not going to be effective in making lasting changes to a place brand. It is also clear that brand managers need to focus on the perception of the place. None of the studies looked at how their social problem related to public perception, only that there was a negative perception of the brand. This review shows that place branding strategies can be successful for places with negative images, in particular social problems, however, it is an all-encompassing process that cannot focus on only one aspect (i.e. promotion or tourism). Brand managers must also look at making product improvements (including policy change and infrastructure development,) that consistently work towards creating a positive brand perception for a place.

The studies identified in this review all have prominent social problems, however they do not identify social problems as being the focus of the study. Some of the identified social problems included, among others, poverty, underdevelopment, political and economic instability, corruption, conflicts, crime, environmental issues, violence and unemployment. All case studies discussed the problem of a negative image and the main reasons behind the negative image, but most of them did not discuss the problem in terms of being a prominent social problem for the place and therefore did not focus on strategy specific to the improvement of social problems. Several of the cases including those that looked at slum tourism (Hernandez-Garcia, 2013; Torres, 2012), Kavaratzis and Ashworth's (2006) study on Amsterdam and Palmer et al.'s (2006) study into specific Australian suburbs highlighted the relevance of social problems in diminishing a place's image and the need for them to be removed from the focal point of the place image.

This review indicates that it is not necessary to remove a social problem before place branding benefits can be seen. Showing progress towards change can encourage investment that boosts place branding efforts. It also shows that policy is important to changing or improving many social problems. In the case of ex-Yugoslavian states partnerships between the countries were recommended to be beneficial in helping reduce the perception of residual political uncertainty and turmoil from previous decades. In both Brooklyn (Parkerson, 2007) and Dundee (Peel \& Lloyd, 2008) housing was a big issue causing social problems for the people. Through efforts focusing on policy development to create more affordable living and better social housing, the problems of dubious business deals and violence were reduced.

\section{Limitations and future research}

The systematic search identified only twenty-five places that had been subject to study in relation to place branding. Indisputably there would be other place branding campaigns for places with prominent social problems that have not been the subject of evaluation and/or that have not been published. As the field is in its infancy, it is important that places that implement place branding strategies document and provide detailed descriptions of the campaigns along with a means of evaluation so that other places in similar positions or being affected by similar circumstances can utilise this information. Any campaign whether successful or not can be learnt from as a guide of what to do and what not to do to develop the most liveable and sustainable places.

There is also much to be learnt from systematic reviews of place branding case studies in other areas, not directly related to the issue of social problems. Therefore other systematic reviews should be carried out, focusing on different types of places (e.g. cities), problems (e.g. increasing inward investment) or the effectiveness of different place branding tools (e.g. communication efforts). Further, the literature indicates that a place branding campaign will be unsuccessful if the brand presented is not congruent with the actual place (Adabola et al., 2012). Studies into the effects of cognitive dissonance in place branding campaigns when 
there is a difference between the brand identity and brand image being presented to external audiences need to be further developed. This is important because social problems have strong impact on place brand perception and make it harder for place branding campaigns to be successful in changing negative perceptions. Finally, more research is needed into the importance of product improvements in changing public perception of places, especially those with social problems. Focus cannot just be to improve and promote the positives of the place as it is likely to be unsuccessful. Research into the success of campaigns where improvements either remove the social problems or minimise their impact on the brand would be beneficial to formulate models for brand managers to follow. Research in this area could also look at collating data on the various successful and unsuccessful policies used by governments to implement place branding. 


\section{References}

Adebola, O., Igbekele, T., Olajide, F. and Lamidi, I. K. (2012) Rebranding Nigeria: the role of advertising and public relations at correcting Nigeria image. International Research Journals 3(5): 424-428.

Anholt, S.

(2005) Some important distinctions in place branding. Place branding 1(2): 116-121.

(2010). Definitions of Place Branding - Working towards a resoultion. Place Branding and Public Diplomacy, 6, 1-10.

Anholt, S. and Hildreth, J. (2004) Brand America: The Mother of All Brands. London, UK: Cyan.

Bigi, A., Plangger, K., Bonera, M. and Campbell, C. L. (2011) When satire is serious: how political cartoons impact a country's brand. Journal of Public Affairs 11(3): 148-155.

Blumer, H. (1971). Social Problems as Collective Behaviour, Social Problems, 18(3), 298306.

Broto, V. C., Burningham, K., Carter, C. and Elghali, L. (2010) Stigma and Attachment: Performance of Identity in an Environmentally Degraded Place. Society and Natural Resources, 23(10): 952.

Brown, S. (2006) Ambi-brand culture. In: J. Schroeder and M. Salzer-Moerling (Eds.), Brand culture, Milton Park: Routledge.

Colocousis, C.R. (2012) "It Was Tourism Repellent, That's What We Were Spraying": Natural Amenities, Environmental Stigma, and Redevelopment in a Postindustrial Mill Town. Sociological Forum 27(3): 756-776.

Cooper, A.F. and Momani, B. (2009) The challenge of re-branding progressive countries in the Gulf and Middle East: Opportunities through new networked engagements versus constraints of embedded negative images. Place Branding and Public Diplomacy 5(2): 103-117.

Dinnie, K. (2004) Place branding: overview of an emerging literature. Place Branding, 1(1): 106-110.

Dijksterhuis, A., \& Bargh, J. A. (2001). The perception-behavior expressway: Automatic effects of social perception on social behavior. Advances in experimental social psychology, 33, 1-40.

Hall, D. (2002) Brand development, tourism and national identity: The re-imaging of former Yugoslavia. Journal of Brand Management 9(4/5): 323-334.

Hankinson, G. (2007) The management of destination brands: Five guiding principles based on recent developments in corporate branding theory. Journal of Brand Management: 14(3): 240-254.

Harmaakorpi, V., Kari, K. and Parjanen, S. (2008) City design management as a local competitiveness factor. Place Branding and Public Diplomacy 4(2): 169-181.

Hernandez-Garcia, J. (2013) Slum tourism, city branding and social urbanism: the case of Medellin, Colombia. Journal of Place Management and Development 6(1): 43-51.

Herstein, R. and Jaffe, E.D. (2008) The children's city -- The transition from a negative to a positive city image. Place Branding and Public Diplomacy 4(1): 76-84.

Hunter, W.C. (2011) Rukai indigenous tourism: Representations, cultural identity and Q method. Tourism Management 32(2): 335-348.

Kaneva, N. and Popescu, D. (2011) National identity lite: Nation branding in post-Communist Romania and Bulgaria. International Journal of Cultural Studies 14(2): 191-207.

Kavaratzis, M. (2004) From city marketing to city branding: towards a theoretical framework for developing city brands. Place Branding 1(1): 58-73.

Kavaratzis, M. and Ashworth, G.J. (2006) Changing the Tide: the Campaign to Re-Brand Amsterdam. European Regional Science Association.

Konecnik, M. and Go, F. (2008) Tourism destination brand identity: The case of Slovenia. Journal of Brand Management, 15(3): 177-177.

Martinovic, S. (2002) Branding Hrvatska - a mixed blessing that might succeed: The advantage of being unrecognisable. Journal of Brand Management 9(4/5): 315-322.

Ndlovu, J. and Heath, E.T. (2011) Destination Branding in Zimbabwe: From Crisis to Recovery. Tourism Analysis 16(1): 87-97.

Ndlovu, J. and Heath, E.T. (2013) Re-Branding of Zimbabwe to enhance sustainable tourism development. African Journal of Business Management 7(12): 947-955.

Niedomysl, T. and Jonasson, M. (2012) Towards a Theory of place Marketing. Journal of Place Management and Development 5(3): 223-230. 
Nuttavuthisit, K. (2007) Branding Thailand: Correcting the negative image of sex tourism. Place Branding and Public Diplomacy 3(1): 21-30.

Nye, J. S. (2004) Soft Power and American Foreign Policy. Political Science Quarterly, 119(2), 256.

Osei, C. and Gbadamosi, A. (2011) Re-branding Africa. Marketing Intelligence and Planning 29(3): 284-304

Palmer, C., Ziersch, A., Arthurson, K. and Baum, F. (2005) "Danger lurks around every corner": fear of crime and its impact on opportunities for social interaction in stigmatised Australian suburbs. Urban policy and research 23(4): 393-411.

Pant, D.R. (2005) A place brand strategy for the Republic of Armenia: 'Quality of context' and 'sustainability' as competitive advantage. Place Branding 1(3): 273-282.

Parkerson, B. (2007) From schlock to hot: Shifting perceptions of Brooklyn. Place Branding and Public Diplomacy 3(4): 263-267.

Peel, D. and Lloyd, G. (2008) New communicative challenges: Dundee, place branding and the reconstruction of a city image. Town Planning Review 79(5): 507-532.

Thio, A. and Taylor, J. D. (2012) Social Problems. Jones and Bartlett Learning, Sudbury, USA.

Torres, I. (2012) Branding slums: a community-driven strategy for urban inclusion in Rio de Janeiro. Journal of Place Management and Development 5(3): 198-211.

Trueman, M., Klemm, M. and Giroud, A. (2004) Can a city communicate? Bradford as a corporate brand. Corporate Communications: An International Journal 9(4): 317-330.

Viosca Jr, R.C., Bergiel, B.J. and Balsmeier, P. (2004) Effects of the electronic Nigerian money fraud on the brand equity of Nigeria and Africa. Management Research News 27(6): 11-20.

Vitic, A. and Ringer, G. (2008) Branding Post-Conflict Destinations. Journal of Travel and Tourism Marketing 23(2-4): 127-137.

Wills, D. and Moore, C. (2008) Securitising the Caucasus: from political violence to place branding in Chechnya. Place Branding and Public Diplomacy 4(3): 252-262. 